UNIT NO. 2

\title{
SARCOPENIA: CAUSES, CONSEQUENCES, PREVENTION AND TREATMENT
}

\author{
Dr Samuel Chew
}

\begin{abstract}
The phenomenon of age-related loss of muscle mass and strength was named sarcopenia in 1988 by Rosenberg. Since then, sarcopenia has evolved to include the loss of muscle function in the definition. Sarcopenia has a high prevalence in specific clinical conditions and in the older population and can lead to significant morbidity, poor recovery from adverse events and ultimately, institutionalisation. In spite of the severe health care burden posed, the diagnosis and treatment of sarcopenia have yet to become standard care. Emerging consensus on definition and diagnosis by the international work groups on sarcopenia with tailored population-based cut-offs and growing evidence-based management options will facilitate the meeting of these needs.
\end{abstract}

Keywords: Sarcopenia, Diagnosis, Aetiology, Consequences, Prevention, Management;

SFP20 I8; 44(5) : I I- I7

\section{INTRODUCTION}

The phenomenon of age-related loss of muscle mass and strength was first reported by Critchley in $1931^{1}$ Rosenberg first used the term sarcopenia to describe the loss of muscle in $1989^{2}$ and this term has since evolved to include the loss of muscle function in the definition. Sarcopenia has a high prevalence in specific clinical conditions and in the older population and can lead to significant impairment of balance, mobility and ability to recover from acute illness, trauma and surgery with subsequent increased risks of recurrent falls, fractures, loss of functional independence and institutionalisation. Although the concepts involved in diagnosis and management of osteoporosis and sarcopenia are similar, the diagnosis and treatment of sarcopenia have yet to become standard care in the at-risk populations.

\section{Epidemiology}

A systematic review and meta-analysis of general population studies of 58,404 individuals, based on the definitions of the European Working Group on Sarcopenia in Older People (EWGSOP), the International Working Group on Sarcopenia

\section{DR SAMUEL CHEW}

Senior Consultant, Geriatic Medicine,

Changi General Hospital, Singapore
(IWGS) and Asian Working Group for Sarcopenia (AWGS), found an overall estimated prevalence of $10 \%$ for both women and men globally. The review also found higher prevalence in non-Asian compared with Asian individuals (11\% vs $10 \%$ in men, $13 \%$ vs $9 \%$ in women). This was suggested as a result of the lower mean appendicular muscle mass in young Asians compared to non-Asians, a difference in dietary intake and level of physical activity. ${ }^{3}$

In ageing adults, the prevalence worldwide ranges from 1-29\% in community settings, $14-33 \%$ in long-term care settings and $10 \%$ in a single acute hospital population reported by the International Sarcopenia Initiative. In most studies, there was no difference with regards to gender. ${ }^{4}$ In individuals above 80 years of age, the prevalence may reach $50 \%$ and is roughly twice as common as frailty in older adults.

A cross-sectional study of 115 patients $>$ 65-years-old attending outpatient specialist clinics in a tertiary referral hospital in Singapore using the screening tool SARC-F suggested that up to $44.3 \%$ were at risk of sarcopenia. ${ }^{6}$ Another community-based cohort study of 186 patients in Singapore using the EWGSOP cut-offs for appendicular lean mass/height ${ }^{2}$ suggested that up to $53.8 \%$ may be sarcopenic. ${ }^{7}$ An on-going study of 800 community dwelling patients > 65-years-old in Singapore at risk of undernutrition with a MUST score of 1 and more will provide more information on the prevalence of sarcopenia in this cohort using the AWGS cut-off values for handgrip strength, gait-speed and lean muscle mass measured by bioimpedence analysis. ${ }^{8}$

\section{Definition}

Using the consensual definitions by EWGSOP, IWGS and AWGS, sarcopenia is defined as the presence of low muscle mass (adjusted appendicular muscle mass for height) and muscle strength (handgrip strength) or physical performance (the usual gait speed).

\section{Diagnosis}

For the Asian context, sarcopenia can be diagnosed based on the AWGS criteria (Figure 1). Individuals are first screened by measuring both handgrip strength and usual gait speed. The cut-offs are $<26 \mathrm{~kg}$ for men and $<18 \mathrm{~kg}$ for women for low handgrip strength, and $<0.8 \mathrm{~m} / \mathrm{s}$ for 6 -meter usual gait speed for both men and women. ${ }^{9}$

If either are positive, the individual can then be further assessed for loss of lean muscle mass by dual energy X-ray absorptiometry (DEXA) or bioimpedence analysis (BIA). The recommended cut-offs are 2 standard deviations below the mean muscle mass of young reference group based on height-adjusted appendicular skeletal mass of $7.0 \mathrm{~kg} / \mathrm{m}^{2}$ in men 
and $5.4 \mathrm{~kg} / \mathrm{m}^{2}$ for women using DEXA, and $7.0 \mathrm{~kg} / \mathrm{m}^{2}$ in men and $5.7 \mathrm{~kg} / \mathrm{m}^{2}$ in women using BIA. ${ }^{9}$

Figure 1: Recommended diagnostic algorithm of Asian Working Group for Sarcopenia

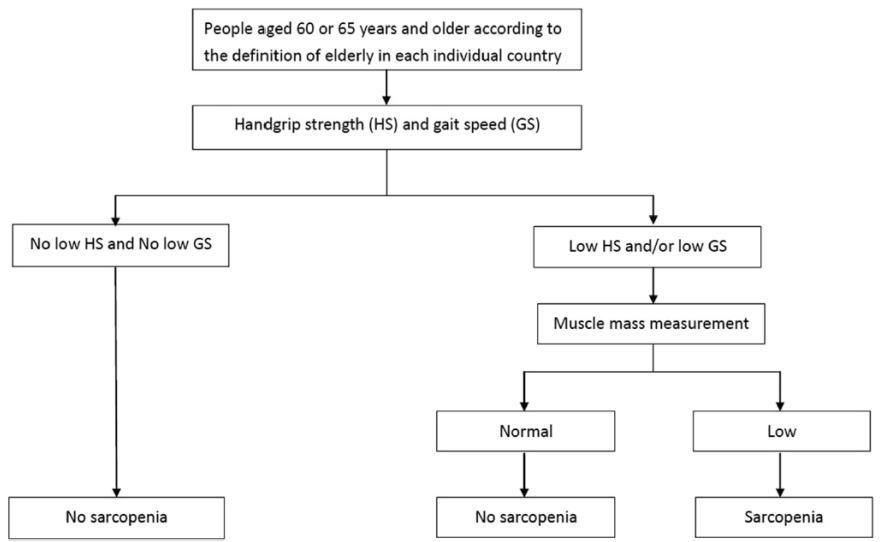

Taking into account the different age cut-off defining elderly population in Asia, AWGS recommends screening at age 60 or 65 and older in community dwelling older people and older people with specific clinical conditions in all healthcare settings (Table 1). ${ }^{?}$

Table 1: Strategy of Sarcopenia Screening and Assessment for Older People (60 or 65 Years of Age and Older) in Asia

Community Settings

People aged 60 or 65 years and older (according to the definitions of elderly ir each individual country) living in communities

Specific Clinical Conditions in All Healthcare Settings

Presence of recent functional decline or functional impairment

Unintentional body weight loss for over $5 \%$ in a month

Depressive mood or cognitive impairment

Repeated falls

Undernutrition

Chronic conditions (eg, chronic heart failure, chronic obstructive pulmonary disease, diabetes mellitus, chronic kidney disease, connective tissue disease, tuberculosis infection, and other chronic wasting conditions)

\section{Causes}

\section{Age-related changes in muscle properties}

In muscles, motor units can be subdivided into three main groups; slow motor units, fast fatigable motor units and fast fatigue-resistant motor units. Slow motor units have the lowest number of muscle fibres and consist of Type I myosin which are rich in myoglobin and mitochondria, making them reddish in colour and able to provide adenosine triphosphate (ATP) via oxidative metabolism of triglycerides and carbohydrates over long periods of time for sustained aerobic activities.

In contrast, fast fatigable motor units have the highest number of muscle fibres and generate more force and contractile velocity than the slow motor units. The individual muscle fibres also have the largest cross-sectional area (CSA) amongst the three groups. Fast fatigable motor units consist of Type IIx myosin, which contains smaller amount of mitochondria and hence generates its energy from the glycolysis of glycogen. This pathway is able to provide large amount of energy over a short period of time and results in maximal power generation in the motor unit, required during activities like sprinting or weight lifting.

The fast-fatigue resistant motor units lie in the middle between the two previous described motor unit types. They are made of Type IIa myosin and are intermediate in CSA between Type I and Type IIx muscle fibres.

Maximum power generation is 4 times greater in the fast-fatigable motor units compared with the slow Type I motor units due to the higher contractile velocity. ${ }^{10}$

\section{Changes in muscle morphology}

Between the ages of 40 and 70, there is an age-related loss of approximately $8 \%$ per decade of muscle mass. This accelerates to about $15 \%$ per decade after 70 years of age.

Although both slow and fast motor units are loss, there is an accelerated loss of fast motor units with atrophy of type II fast fibres. ${ }^{11,12}$ This loss is mediated via denervation of the fast motor units, resulting in the recruitment of the surviving denervated motor units by the slow motor units. Once recruited, they are then transformed into slow motor unit types, hence decreasing dramatically the power generating capability of the muscle.

Age related neurodegeneration occurs at all levels of the nervous system and there is a substantial decline in the number of alpha motor neurones in the spinal cord, particularly those supplying the fast motor units. Neuromuscular junctions are decreased in numbers but increase in the size of the terminal areas along with a reduction of the number of synaptic vesicles. ${ }^{13,14}$

In addition, there is an increase in lipid content in the ageing muscle. This takes the form of increased number of adipocytes and direct deposition of lipids within the muscle fibres.

\section{Altered muscle protein metabolism}

Muscle protein metabolism is a dynamic process balancing synthesis from and breakdown of muscle proteins into amino acids. With ageing, there are reduced expression of hormonal factors which promote protein synthesis and increased expression of both endocrine and inflammatory factors which promotes muscle degradation (Figure 2). ${ }^{15}$

Figure 2. Skeletal protein turnover

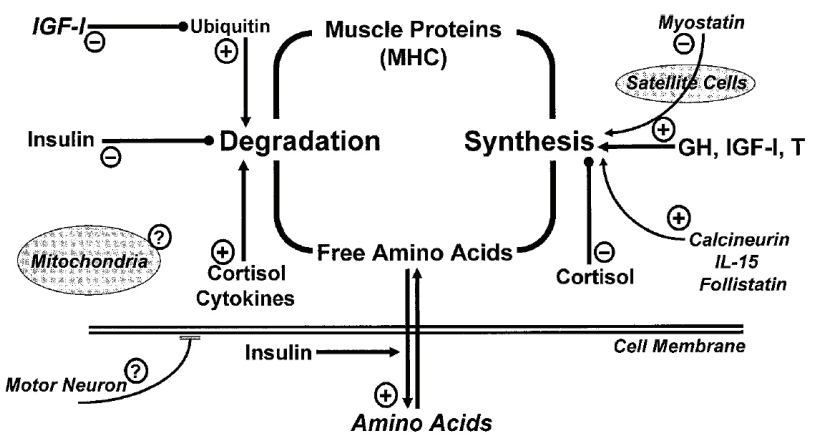




\section{Insulin-like growth factor I (IGF-I)}

IGF-1 promotes protein synthesis in skeletal muscles via the binding and proliferation of skeletal muscle precursor cells. ${ }^{16}$ IGF-1 is produced in the liver via the interaction with growth hormone $(\mathrm{GH})$ and also locally within the skeletal muscles as a response to physical activity. ${ }^{17}$ The actions of IGF-1 are anabolic, anticatabolic and antiapoptotic. ${ }^{18}$ With ageing, there is a decline in the level of GH and consequently, a decline in both liver and skeletal muscle produced IGF-1.

\section{Catabolic mediators}

In cancer cachexia and autoimmune disorders, muscle protein degradation is accelerated and synthesis reduced. ${ }^{19,20}$ The ubiquitin-proteasome pathway is responsible for protein degradation in skeletal muscle cells and involves a series of enzymatic steps leading ultimately to the ubiquitinised proteins transferred to a proteasome complex for degradation into short peptides and free intracellular amino acids ${ }^{21}$ [Lang $\mathrm{T}$, Osteoporosis, 2010;42]. This pathway is promoted by inflammatory cytokines such as tumour necrosis alpha (TNF-a) and interleukin-6 (IL-6), hormones such as cortisol and angiotensin, and reactive oxygen species. In ageing skeletal muscles, there are also increased expression of these mediators. ${ }^{22}$

\section{Oxidative damage}

Although the exact mechanisms are still unclear, the generation and accumulation of reactive oxygen species as part of the oxidative metabolism cycle in mitochondria leads to the damage of both structure and DNA of the mitochondria itself. The frequency of these abnormal mitochondrial DNA regions is higher in muscles affected by sarcopenia. ${ }^{23,24,25}$

\section{Intrinsic skeletal changes}

The ability of the muscle to regenerate itself depends on the number and function of the intrinsic muscle satellite cells which are able to proliferate and differentiate into new skeletal muscle fibres. They are regulated by myogenic regulatory factors (MRF) which stimulates the proliferation and differentiation of the skeletal muscle satellite cells, while inhibitory muscle factors such as myostatin suppresses these activities by suppressing the expressions of the MRFs. ${ }^{26}$ Some studies have reported a reduction in the number of muscle satellite cells, ${ }^{27}$ while others have found wither no change or an increase with ageing. ${ }^{28}$

\section{Changes in the muscle-tendon system}

Human movement requires the transmission of the contractile forces generated by the muscles to the skeletal system via the connecting tendons. If tendons losses their stiffness with age, there is a reduction in the rate of force generation from muscle contraction and vice versa. Initial human studies suggest that there is a 15\% increase in compliance in older subjects compared with younger ones. ${ }^{29}$ Exercise training may be able to counteract this ageing effect by increasing tendon stiffness. ${ }^{30}$

\section{Consequences}

\section{Loss of muscle mass and muscle power}

The most important consequence of sarcopenia is the associated loss of skeletal contractile power, particularly in the lower limb which is essential for functional movements such as rising from a chair or climbing up stairs. Loss of lower limb power and strength is the largest risk factor for falls, injury and disability. ${ }^{31,32}$ Ability to regain balance after a trip or near fall would also be lost. Studies comparing normal young subjects in the 20 to 40 years age range and healthy older subjects in the 70 to 80 years age range have shown a $20 \%$ to $40 \%$ decline in knee extensor torque and power. ${ }^{33-37}$ There is a similar decline of muscle strength in the upper limbs of $20 \%-40 \%$ in measures such as handgrip strength and elbow extension torque between healthy younger and older subjects, with longitudinal declines ranging from $1 \%$ to $5 \%$ per annum. ${ }^{38}$

Studies of muscle CSA have found that CSA decrease by roughly $40 \%$ between 20 and 60 years old ${ }^{39,40}$ and longitudinal studies of leg lean mass by DXA suggest that there is a roughly $1 \%$ loss per annum. ${ }^{38}$

\section{Clinical impact}

Prospective cohort studies have shown the correlation between sarcopenia and adverse clinical outcomes in the older population, including falls, disability and fractures..$^{31,32,41}$ Measures of lower-body weakness defined as increased chair stand time and reduced knee extension strength have been correlated with odds ratios for any falls, injurious falls or recurrent falls, with highest correlation for recurrent falls with odds ratios ranging from 2.2 to $9.9 .{ }^{32}$ Upper body weakness is also correlated with falls risk, albeit at a lower magnitude.

Low thigh muscle CSA, low knee extensor power and torque are associated with increased risk of future inability to perform daily activities and limitation in functional mobility, defined as ability to climb 10 flights of stairs or walk quarter of a mile. ${ }^{42}$ There is also an association between low knee extension torque and increased risk of hip fracture of $50 \%$ to $60 \%$, independent of bone mineral density. ${ }^{43}$

\section{Prevention}

\section{Nutrition}

Recent research has found that older adults need more dietary protein than younger peers to maintain good health, promote recovery from illness and maintain functionality, due in part to the increase anabolic resistance in the older population. ${ }^{44-49}$ Evolving evidence supports the concept that lean body mass can be better maintained in older adults by consuming dietary protein at a higher level than the general recommended daily allowance (RDA). ${ }^{45} 51$ The PROT-AGE Study Group have recommended a daily intake of 1.0 to $1.2 \mathrm{~g}$ protein per $\mathrm{kg}$ of body weight per day. For active older adults whom are also exercising, a higher protein intake of $>1.2 \mathrm{~g}$ per $\mathrm{kg}$ of body 
weight is recommended. ${ }^{52}$

Protein ingestion together with exercise training increases the synthesis of skeletal muscle ${ }^{53-57}$, in both aerobic ${ }^{55,58}$ and resistance ${ }^{53,54,57}$ exercises. Net positive protein balance was achieved only when protein or amino acid intake was supplemented. ${ }^{59,60}$ High-leucine-containing and rapidly digested whey proteins had more effect on muscle protein synthesis than casein or soy proteins in isolation..$^{53,54,57,61}$

An age-related decline in $\beta$-Hydroxy $\beta$-Methyl Butyrate (HMB), a metabolite of the amino acid leucine, has been found in humans. There is also a positive correlation between HMB concentrations with muscle mass and appendicular grip strength in adults. ${ }^{62} \mathrm{HMB}$ supplementation during 10 days of bed rest have been shown to preserve muscle mass in healthy older adults $^{63}$ and a meta-analysis of seven randomised controlled clinical trials of 287 subjects suggests that HMB supplementation can contribute to the preservation of muscle mass in older adults. ${ }^{64}$

In the post-hoc analysis of the PROVIDE study, a greater muscle gain was found in patients with a higher baseline serum 25-hydroxyvitamin D $(25(\mathrm{OH}) \mathrm{D})$. Vitamin D acts synergistically with leucine and insulin to stimulate muscle protein synthesis. Older adults with deficient baseline concentrations may need a higher dose of vitamin $\mathrm{D}$ or longer supplementation to achieve desirable serum $25(\mathrm{OH}) \mathrm{D}$ concentrations of 20 to $40 \mathrm{micrograms} / \mathrm{L} .{ }^{65}$

\section{Exercise}

Maintenance of muscle mass and strength is critical for the preservation of physical activity and reducing the risks of falls and fractures in the older population. In addition, muscles exert powerful loads on the skeleton and leads to an adaptive increase in bone mass and strength, potentially further reducing the fracture risks. ${ }^{66}$

A study of active older seniors from the University of Southern California longitudinal study on master athletes suggest that the fitness and functional reserves in these individuals are comparable to sedentary individuals 20 years their junior. ${ }^{67,68}$ These gains need to be sustained by continuous exercise or they will be lost within a few years.

Resistive training can counteract age-related muscle loss by increasing both the number and the CSA of skeletal muscle fibres in both older men and women. The benefits are seen after 12 weeks of training, seem to be sustained even after cessation of the training period and extend to the frail population in nursing homes. ${ }^{69-73}$ The resistive training exercises requires modest resources only, with sessions of 30 minutes twice a week using either exercise machines, body weight or elastic bands. Concurrent additional benefits are also seen in relation with osteoporosis, osteoarthritis, heart disease, diabetes and depression.

\section{Treatment}

\section{Hormone replacement}

Testosterone has an anabolic effect on muscle protein synthesis. Oestrogen, which can be converted to testosterone, will hence also impact on muscle strength. In addition, both sex hormones suppress inflammatory cytokine production. However, trials of oestrogen and testosterone therapy in women have not led to significant increases of muscle strength. ${ }^{74}$ In men, there are significant improvement in lean body mass and muscle strength in young hypogonadal men treated with testosterone therapy, albeit still less than the improvements from resistive training. ${ }^{75-77}$ In older hypogonadal men treated with testosterone, there are some minimal change in body composition but no increase in muscle strength observed in studies which included control groups for comparison. ${ }^{74}$

The use of growth hormone as a potential anabolic agent for muscle synthesis has also been studied but most studies have found no improvements in both muscle mass and muscle strength in the elderly. Other approaches include the use of growth-hormone-releasing hormone which increases the level of $\mathrm{GH}$ and lead to moderate improvement in muscle strength. ${ }^{74-78}$ The use of IGF-I alone can lead to hypoglycaemia limiting the safe dose but this can be addressed by binding IGF-I to the binding protein IGFBP-3 and the use of this complex have been associated with increased grip strength in older women post hip fracture. ${ }^{79,80}$

Other agents under investigation include inhibitors of myostatin as myostatin counteracts the myogenic regulatory factors which promote the differentiation and proliferation of myocytes. Studies are also being done with selective androgen receptor modulators (SARMs) which can potentially selectively bind the androgen receptor in skeletal muscles and bones, and less stimulative effect on the prostate.

\section{Conclusion}

Sarcopenia is the result of a multifactorial process developing over a long period of time, leading to a loss of muscle mass, strength and function.

With the rise in ageing population globally, there is an urgent need to address the morbidity and loss of independence as a result of sarcopenia in order to add more functional and independence-filled life to years and enable true ageing in place. Nutrition and exercise play key roles in moderating these age-related losses and at the same time help maintain mobility, function and independent living. Naturally and directly, this will reduce the morbidity and mortality associated with falls, factures and osteoporosis.

Emerging consensus on definition and diagnosis by the international work groups on sarcopenia with tailored population-based cut-offs and growing evidence-based management options will facilitate urgent action, by clinicians and researchers alike, in meeting these needs. 


\section{REFERENCES}

I. Critchley M. The neurology of old age. The Lancet. I93I May 23;2I7(562I): I II9-27.

2. Rosenberg IH. Summary comments. The American journal of clinical nutrition. 1989 Nov I;50(5): I23 I-3.

3. Shafiee G, Keshtkar A, Soltani A, Ahadi Z, Larijani B, Heshmat R. Prevalence of sarcopenia in the world: a systematic review and metaanalysis of general population studies. Journal of Diabetes \& Metabolic Disorders. 2017 Dec; 16(I):2I

4. Cruz-Jentoft AJ, Landi F, Schneider SM, Zúñiga C, Arai H, Boirie Y, Chen LK, Fielding RA, Martin FC, Michel JP, Sieber C. Prevalence of and interventions for sarcopenia in ageing adults: a systematic review. Report of the International Sarcopenia Initiative (EWGSOP and IWGS). Age and ageing. 2014 Sep 21;43(6):748-59.

5. Morley JE. Sarcopenia: diagnosis and treatment. The Journal of Nutrition Health and Aging. 2008 Sep I; I2(7):452.

6. Tan LF, Lim ZY, Choe R, Seetharaman S, Merchant R. Screening for frailty and sarcopenia among older persons in medical outpatient clinics and its associations with healthcare burden. Journal of the American Medical Directors Association. 2017 Jul I; I8(7):583-7.

7. Koh AS, Wong JI, Yew WY, Chua SJ, Huang F, Leng S, Zhong L, Lee SY, Gao F, Tan RS, Koh WP. SARCOPENIA AND VASCULAR FUNCTION AMONG COMMUNITY ELDERLY. Journal of the American College of Cardiology. 2017 Mar 21;69(II Supplement):205I . 8. ClinicalTrials.gov [Internet]. Bethesda (MD): National Library of Medicine (US). 2000 Feb 29 - . Identifier NCT03245047, The Nutritional Health for the Elderly Reference Centre Study (The NHERC Study); 2017 Aug 10 [cited 2018 Aug 27]; [about 4 screens]. Available from: https://clinicaltrials.gov/ct2/show/NCT03245047.

9. Chen LK, Liu LK, Woo J, Assantachai P, Auyeung TW, Bahyah KS, Chou MY, Chen LY, Hsu PS, Krairit O, Lee JS. Sarcopenia in Asia: consensus report of the Asian Working Group for Sarcopenia. Journal of the American Medical Directors Association. 2014 Feb I;I5(2):95-I0I. I0. Lang T, Streeper T, Cawthon P, Baldwin K, Taaffe DR, Harris TB. Sarcopenia: etiology, clinical consequences, intervention, and assessment. Osteoporosis international. 2010 Apr I;2I(4):543-59.

I I. Lexell J, Downham DY. The occurrence of fibre-type grouping in healthy human muscle: a quantitative study of cross-sections of whole vastus lateralis from men between 15 and 83 years. Acta neuropathologica. I99I Mar I;8I(4):377-8I.

12. Lexell J, Downham DY, Larsson Y, Bruhn E, Morsing B.

Heavy-resistance training in older Scandinavian men and women: short-and long-term effects on arm and leg muscles. Scandinavian journal of medicine \& science in sports. 1995 Dec;5(6):329-4I.

13. Ramirez V, Ulfhake B. Anatomy of dendrites in motoneurons supplying the intrinsic muscles of the foot sole in the aged cat: evidence for dendritic growth and neo-synaptogenesis. Journal of Comparative Neurology. I992 Feb 1;316(I): I-6.

14. Kullberg S, Ramírez-León V, Johnson H, Ulfhake B. Decreased axosomatic input to motoneurons and astrogliosis in the spinal cord of aged rats. The Journals of Gerontology Series A: Biological Sciences and Medical Sciences. 1998 Sep 1;53(5):B369-79.

I5. Marcell TJ. Sarcopenia: causes, consequences, and preventions. The Journals of Gerontology Series A: Biological Sciences and Medical Sciences. 2003 Oct I;58(10):M9I I-6.

16. Florini JR, Ewton DZ, Falen SL, Van Wyk JJ. Biphasic concentration dependency of stimulation of myoblast differentiation by somatomedins. American Journal of Physiology-Cell Physiology. 1986 May I;250(5):C77I-8.

17. Goldspink G, Yang SY. 2 The Splicing of the IGF-I Gene to Yield Different Muscle Growth Factors. Advances in genetics. 2004 Jan I;52:23-50.

18. Firth SM, Baxter RC. Cellular actions of the insulin-like growth factor binding proteins. Endocrine reviews. 2002 Dec I;23(6):824-54.

19. Rasmussen BB, Fujita S, Wolfe RR, Mittendorfer B, Roy M, Rowe VL, Volpi $E$. Insulin resistance of muscle protein metabolism in aging. The FASEB journal. 2006 Apr;20(6):768-9.
20. Kandarian SC, Jackman RW. Intracellular signaling during skeletal muscle atrophy. Muscle \& nerve. 2006 Feb I;33(2):I55-65.

2I. Reid MB. Response of the ubiquitin-proteasome pathway to changes in muscle activity. American Journal of Physiology-Regulatory, Integrative and Comparative Physiology. 2005 Jun;288(6):RI423-3I.

22. Giresi PG, Stevenson EJ, Theilhaber J, Koncarevic A, Parkington J, Fielding RA, Kandarian SC. Identification of a molecular signature of sarcopenia. Physiological genomics. 2005 Apr 14;2I (2):253-63.

23. Hiona $A$, Leeuwenburgh $C$. The role of mitochondrial DNA mutations in aging and sarcopenia: implications for the mitochondrial vicious cycle theory of aging. Experimental gerontology. 2008 Jan I;43(I):24-33

24. Dirks AJ, Hofer T, Marzetti E, Pahor M, Leeuwenburgh C. Mitochondrial DNA mutations, energy metabolism and apoptosis in aging muscle. Ageing research reviews. 2006 May I;5(2): I79-95.

25. Herbst A, Pak JW, McKenzie D, Bua E, Bassiouni M, Aiken JM. Accumulation of mitochondrial DNA deletion mutations in aged muscle fibers: evidence for a causal role in muscle fiber loss. The Journals of Gerontology Series A: Biological Sciences and Medical Sciences. 2007 Mar 1;62(3):235-45.

26. McCroskery S, Thomas M, Maxwell L, Sharma M, Kambadur R. Myostatin negatively regulates satellite cell activation and self-renewal. The Journal of cell biology. 2003 Sep 15; I62(6): I I35-47.

27. Conboy IM, Conboy MJ, Smythe GM, Rando TA. Notch-mediated restoration of regenerative potential to aged muscle. Science. $2003 \mathrm{Nov}$ 28;302(5650): I575-7.

28. Dreyer HC, Blanco CE, Sattler FR, Schroeder ET, Wiswell RA. Satellite cell numbers in young and older men 24 hours after eccentric exercise. Muscle \& Nerve: Official Journal of the American Association of Electrodiagnostic Medicine. 2006 Feb;33(2):242-53.

29. Narici MV, Maffulli N, Maganaris CN. Ageing of human muscles and tendons. Disability and rehabilitation. 2008 Jan I;30(20-22): I548-54. 30. Reeves ND, Narici MV, Maganaris CN. Strength training alters the viscoelastic properties of tendons in elderly humans. Muscle \& Nerve: Official Journal of the American Association of Electrodiagnostic Medicine. 2003 Jul;28(I):74-8I.

3I. Nevitt MC, Cummings SR, Kidd S, Black D. Risk factors for recurrent nonsyncopal falls: a prospective study. Jama. 1989 May

I2;26I( I8):2663-8.

32. Moreland JD, Richardson JA, Goldsmith CH, Clase CM. Muscle weakness and falls in older adults: a systematic review and meta-analysis. Journal of the American Geriatrics Society. 2004 Jul I;52(7): I I 2 I-9.

33. Larsson L, Grimby G, Karlsson J. Muscle strength and speed of movement in relation to age and muscle morphology. Journal of Applied Physiology. 1979 Mar 1;46(3):45 I-6.

34. Murray MP, Duthie EH, Gambert SR, Sepic SB, Mollinger LA. Age-related differences in knee muscle strength in normal women. Journal of gerontology. 1985 May I;40(3):275-80.

35. Murray MP, Gardner GM, Mollinger LA, Sepic SB. Strength of isometric and isokinetic contractions: knee muscles of men aged 20 to 86. Physical therapy. 1980 Apr I;60(4):4I2-9.

36. Young A, Stokes M, Crowe M. Size and strength of the quadriceps muscles of old and young women. European journal of clinical investigation. 1984 Aug; 14(4):282-7.

37. Young A, Stokes M, Crowe M. The size and strength of the quadriceps muscles of old and young men. Clinical physiology (Oxford,

England). 1985 Apr;5(2): |45-54

38. Doherty TJ. Invited review: aging and sarcopenia. Journal of applied physiology. 2003 Oct;95(4): I7|7-27.

39. Porter MM, Vandervoort AA, Lexell J. Aging of human muscle: structure, function and adaptability. Scandinavian journal of medicine \& science in sports. 1995 Jun;5(3): I29-42.

40. Vandervoort AA. Aging of the human neuromuscular system. Muscle \& Nerve: Official Journal of the American Association of Electrodiagnostic Medicine. 2002 Jan;25(I): I7-25.

4I. Visser M, Kritchevsky SB, Goodpaster BH, Newman AB, Nevitt M, Stamm E, Harris TB. Leg muscle mass and composition in relation to 
lower extremity performance in men and women aged 70 to 79: the health, aging and body composition study. Journal of the American Geriatrics Society. 2002 May;50(5):897-904.

42. Visser M, Goodpaster BH, Kritchevsky SB, Newman AB, Nevitt M, Rubin SM, Simonsick EM, Harris TB. Muscle mass, muscle strength, and muscle fat infiltration as predictors of incident mobility limitations in well-functioning older persons. The Journals of Gerontology Series A: Biological Sciences and Medical Sciences. 2005 Mar 1;60(3):324-33. 43. Lang T, Cauley JA, Tylavsky F, Bauer D, Cummings S, Harris TB. Computed tomographic measurements of thigh muscle cross-sectional area and attenuation coefficient predict hip fracture: the health, aging, and body composition study. Journal of Bone and Mineral Research. 2010 Mar;25(3):5।3-9.

44. Walrand S, Guillet C, Salles J, Cano N, Boirie Y. Physiopathological mechanism of sarcopenia. Clinics in geriatric medicine. 20II Aug 1;27(3):365-85

45. Gaffney-Stomberg E, Insogna KL, Rodriguez NR, Kerstetter JE. Increasing dietary protein requirements in elderly people for optimal muscle and bone health. Journal of the American Geriatrics Society. 2009 Jun;57(6): 1073-9.

46. Kurpad AV, Vaz M. Protein and amino acid requirements in the elderly. European journal of clinical nutrition. 2000 Jun I;54(S3):SI3I. 47. Morse MH, Haub MD, Evans WJ, Campbell WW. Protein requirement of elderly women: nitrogen balance responses to three levels of protein intake. The Journals of Gerontology Series A: Biological Sciences and Medical Sciences. 200 I Nov I;56( I I):M724-30.

48. Chernoff R. Protein and older adults. Journal of the American

College of Nutrition. 2004 Dec 1;23(sup6):627S-30S.

49. Morley JE, Argiles JM, Evans WJ, Bhasin S, Cella D, Deutz NE, Doehner W, Fearon KC, Ferrucci L, Hellerstein MK, Kalantar-Zadeh K. Nutritional recommendations for the management of sarcopenia. Journal of the american Medical Directors association. 2010 Jul I; I I (6):39I-6.

50. Walrand S, Guillet C, Boirie Y. Nutrition, protein turnover and muscle mass. Sarcopenia. 2012 Aug 30:59-73.

5I. Campbell WW, Trappe TA, Wolfe RR, Evans WJ. The recommended dietary allowance for protein may not be adequate for older people to maintain skeletal muscle. The Journals of Gerontology Series A: Biological Sciences and Medical Sciences. 200I Jun I;56(6):M373-80. 52. Bauer J, Biolo G, Cederholm T, Cesari M, Cruz-Jentoft AJ, Morley JE, Phillips S, Sieber C, Stehle P, Teta D, Visvanathan R. Evidence-based recommendations for optimal dietary protein intake in older people: a position paper from the PROT-AGE Study Group. Journal of the american Medical Directors association. 2013 Aug I; I4(8):542-59. 53. Yang Y, Breen L, Burd NA, Hector AJ, Churchward-Venne TA, Josse AR, Tarnopolsky MA, Phillips SM. Resistance exercise enhances myofibrillar protein synthesis with graded intakes of whey protein in older men. British Journal of nutrition. 2012 Nov; 108(I0): 1780-8. 54. Burd NA, Yang Y, Moore DR, Tang JE, Tarnopolsky MA, Phillips SM. Greater stimulation of myofibrillar protein synthesis with ingestion of whey protein isolate $\mathrm{v}$. micellar casein at rest and after resistance exercise in elderly men. British Journal of nutrition. 2012 Sep; 108(6):958-62.

55. Fujita S, Rasmussen BB, Cadenas JG, Drummond MJ, Glynn EL, Sattler FR, Volpi E. Aerobic exercise overcomes the age-related insulin resistance of muscle protein metabolism by improving endothelial function and Akt/mammalian target of rapamycin signaling. Diabetes. 2007 Jun I;56(6):1615-22.

56. Cermak NM, de Groot LC, Saris WH, van Loon LJ. Protein supplementation augments the adaptive response of skeletal muscle to resistance-type exercise training: a meta-analysis-. The American journal of clinical nutrition. 2012 Nov 7;96(6): I454-64.

57. Yang Y, Churchward-Venne TA, Burd NA, Breen L, Tarnopolsky MA, Phillips SM. Myofibrillar protein synthesis following ingestion of soy protein isolate at rest and after resistance exercise in elderly men. Nutrition \& metabolism. 2012 Dec;9(I):57.

58. Timmerman KL, Dhanani S, Glynn EL, Fry CS, Drummond MJ, Jennings K, Rasmussen BB, Volpi E. A moderate acute increase in physical activity enhances nutritive flow and the muscle protein anabolic response to mixed nutrient intake in older adults-. The American journal of clinical nutrition. 20I2 May 9;95(6): I403-I2.

59. Biolo G, Tipton KD, Klein S, Wolfe RR. An abundant supply of amino acids enhances the metabolic effect of exercise on muscle protein. American Journal of Physiology-Endocrinology And Metabolism. $1997 \mathrm{Ju}$ I;273(I):EI 22-9.

60. Drummond MJ, Marcus RL, LaStayo PC. Targeting anabolic impairment in response to resistance exercise in older adults with mobility impairments: potential mechanisms and rehabilitation approaches. Journal of aging research. 2012;20I2.

6I. Pennings B, Boirie Y, Senden JM, Gijsen AP, Kuipers H, van Loon LJ. Whey protein stimulates postprandial muscle protein accretion more effectively than do casein and casein hydrolysate in older men-. The American journal of clinical nutrition. 20I I Mar 2;93(5):997-I005. 62. Kuriyan R, Lokesh DP, Selvam S, Jayakumar J, Philip MG, Shreeram S, Kurpad AV. The relationship of endogenous plasma concentrations of B -Hydroxy в -Methyl Butyrate (HMB) to age and total appendicular lean mass in humans. Experimental gerontology. 2016 Aug 1;81:13-8. 63. Deutz NE, Pereira SL, Hays NP, Oliver JS, Edens NK, Evans CM, Wolfe RR. Effect of $B$-hydroxy-B -methylbutyrate (HMB) on lean body mass during 10 days of bed rest in older adults. Clinical nutrition. 2013 Oct I;32(5):704-12.

64. Wu H, Xia Y, Jiang J, Du H, Guo X, Liu X, Li C, Huang G, Niu K. Effect of beta-hydroxy-beta-methylbutyrate supplementation on muscle loss in older adults: a systematic review and meta-analysis. Archives of gerontology and geriatrics. 2015 Sep I;6I (2): I68-75.

65. Verlaan S, Maier AB, Bauer JM, Bautmans I, Brandt K, Donini LM, Maggio M, McMurdo ME, Mets T, Seal C, Wijers SL. Sufficient levels of 25-hydroxyvitamin $D$ and protein intake required to increase muscle mass in sarcopenic older adults-The PROVIDE study. Clinical Nutrition. 2018 Apr I;37(2):55।-7.

66. Suominen $\mathrm{H}$. Muscle training for bone strength. Aging clinical and experimental research. $2006 \mathrm{Apr}$ I; 18(2):85-93.

67. Hawkins SA, Marcell TJ, Victoria SJ, Wiswell RA. A longitudinal assessment of change in $\mathrm{VO} 2 \mathrm{max}$ and maximal heart rate in master athletes. Medicine and science in sports and exercise. 200I

Oct;33(I0): 1744-50.

68. Hawkins SA, Wiswell RA. Rate and mechanism of maximal oxygen consumption decline with aging. Sports medicine. $2003 \mathrm{Oct}$ I;33(I2):877-88

69. Frontera WR, Meredith CN, O'Reilly KP, Knuttgen HG, Evans WJ. Strength conditioning in older men: skeletal muscle hypertrophy and improved function. Journal of applied physiology. $1988 \mathrm{Mar}$ I;64(3): 1038-44.

70. Charette S, McEvoy L, Pyka G, Snow-Harter C, Guido D, Wiswell RA, Marcus R. Muscle hypertrophy response to resistance training in older women. Journal of applied Physiology. 199| May 1;70(5):1912-6. 7I. Henwood TR, Taaffe DR. Detraining and retraining in older adults following long-term muscle power or muscle strength specific training. The Journals of Gerontology Series A: Biological Sciences and Medical Sciences. 2008 Jul I;63(7):75I-8.

72. Fiatarone MA, Marks EC, Ryan ND, Meredith CN, Lipsitz LA, Evans WJ. High-intensity strength training in nonagenarians: effects on skeletal muscle. Jama. 1990 Jun 13;263(22):3029-34.

73. Fiatarone MA, O'neill EF, Ryan ND, Clements KM, Solares GR, Nelson ME, Roberts SB, Kehayias J], Lipsitz LA, Evans WJ. Exercise training and nutritional supplementation for physical frailty in very elderly people. New England Journal of Medicine. 1994 Jun 23;330(25):1769-75. 74. Borst SE. Interventions for sarcopenia and muscle weakness in older people. Age and ageing. 2004 Sep 22;33(6):548-55.

75. Wang C, Swerdloff RS, Iranmanesh A, Dobs A, Snyder PJ, Cunningham G, Matsumoto AM, Weber T, Berman the Testosterone Gel Study Group N. Transdermal testosterone gel improves sexual function, mood, muscle strength, and body composition parameters in hypogonadal men. The Journal of Clinical Endocrinology \& Metabolism. 2000 Aug I;85(8):2839-53. 
76. Bhasin S, Storer TW, Berman N, Yarasheski KE, Clevenger B, Phillips J, Lee WP, Bunnell TJ, Casaburi R. Testosterone replacement increases fat-free mass and muscle size in hypogonadal men. The Journal of Clinical Endocrinology \& Metabolism. 1997 Feb I;82(2):407-I3.

77. Brodsky IG, Balagopal P, Nair KS. Effects of testosterone replacement on muscle mass and muscle protein synthesis in hypogonadal men--a clinical research center study. The Journal of Clinical Endocrinology \& Metabolism. 1996 Oct I;8I(10):3469-75.

78. Fuh VL, Bach MA. Growth hormone secretagogues: mechanism of action and use in aging. Growth Hormone \& IGF Research. $1998 \mathrm{Feb}$ I;8(I):I3-20.
79. Giovannini S, Marzetti E, Borst SE, Leeuwenburgh C. Modulation of GH/IGF-I axis: potential strategies to counteract sarcopenia in older adults. Mechanisms of ageing and development. 2008 Oct I; I29(I0):593601 .

80. Boonen S, Rosen C, Bouillon R, Sommer A, McKay M, Rosen D, Adams S, Broos P, Lenaerts J, Raus J, Vanderschueren D. Musculoskeletal effects of the recombinant human IGF-I/IGF binding protein-3 complex in osteoporotic patients with proximal femoral fracture: A double-blind, placebo-controlled pilot study. The Journal of Clinical Endocrinology \& Metabolism. 2002 Apr 1;87(4):1593-9.

\section{LEARNING POINTS}

- Sarcopenia is an age-related syndrome associated with loss of muscle mass, strength, function and leads to increased morbidity and mortality in the presence of other insults and hospitalisation.

- The loss of strength and function, then predisposes to more physical immobility and reduced nutritional intake, further aggravating loss of muscle and function leading to a vicious cycle with falls, fractures, disability and institutionalisation as the final outcomes.

- This vicious self-perpetuating cycle can be disrupted with screening of high risk groups, early diagnosis, identifying and treatment of reversible aggravating factors, high protein diet with/without evidence-based micronutrients which promote muscle protein synthesis, and targeted sustained physical exercises.

- Although targeted resistance provides the best outcomes in terms of muscle strength, balance and functional capacity, significant benefits in terms of balance and functional capacity are obtained from sustained self-paced walking exercises and should be encouraged in the community setting. 